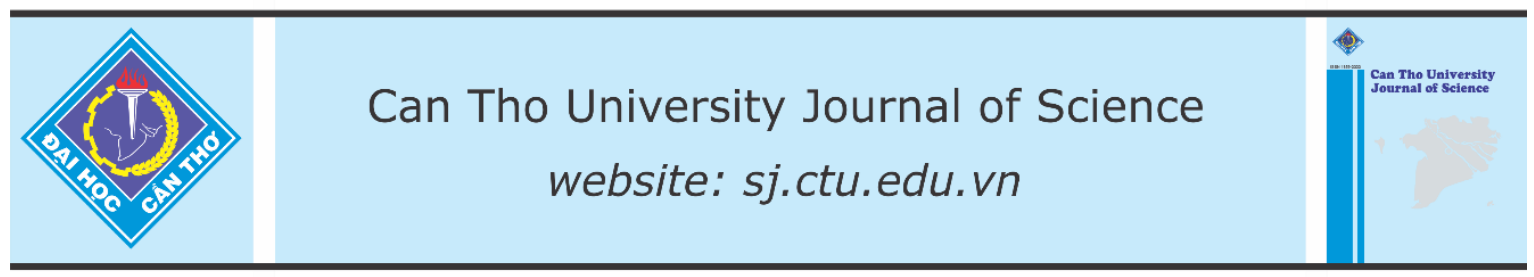

DOI: $10.22144 /$ ctu.jen.2020.008

\title{
Extraction, isolation and identification of four methoxyflavones from leaves of Muntingia calabura $\mathbf{L}$.
}

Ngo Quoc Luan ${ }^{1}$, Tiet Bao Tinh ${ }^{1}$, Ngo Khac Khong Minh², Nguyen Phuc Dam, Tran Thi Tuyet Hoa ${ }^{1}$ and Nguyen Trong Tuan ${ }^{1 *}$

${ }^{\text {I}}$ Can Tho University, Vietnam

${ }^{2}$ Nam Can Tho University, Vietnam

*Correspondence: Nguyen Trong Tuan (email: trongtuan@ctu.edu.vn)

\section{Article info.}

Received 15 Dec 2019

Revised 25 Mar 2020

Accepted 31 Mar 2020

\section{Keywords}

Muntingia calabura L., methoxyflavones

Cited as: Luan, N.Q., Tinh, T.B., Minh, N.K.K., Dam, N.P., Hoa, T.T.T. and Tuan, N.T., 2020. Extraction, isolation and identification of four methoxyflavones from leaves of Muntingia calabura L.. Can Tho University Journal of Science. 12(1): 58-62.

\section{INTRODUCTION}

Jamaica cherry (scientific name is Mungtingia calabura L.) or "cây trứng cá" in Vietnamese belonging to the family Muntingiaceae has been widely grown in almost all tropical regions and thrives in acidic, alkaline or drought soil environments (Pereira et al., 2018). Studies on the biological activity of Mungtingia calabura have shown that this plant had antibacterial and antifungal properties against Escherichia coli, Staphylococcus aureus, Pseudomonas aeruginosa, Candida albicans, Microsporum canis and gave effective cancer cell suppression (Mahmood et al., 2014). Mungtingia calabura contained steroid, tannin, saponin, phenolic and flavonoid compounds. These flavonoids including flavans, flavones, biflavans, chalcones were very diverse in structure and occupied large amounts. Chen et al. (2004) isolated fifteen compounds from the stem bark of Muntingia calabura. Among these compounds, three flavones, namely 8-hydroxy$7,3^{\prime}, 4^{\prime}, 5^{\prime}$-tetramethoxyflavone, $\quad 8,4^{\prime}$-dihydroxy7,3',5'-trimethoxyflavone and 3-hydroxy-1-(3,5-dimethoxy-4-hydroxyphenyl) propan-1-one exhibited effective cytotoxicity with $\mathrm{ED}_{50}$ values of 3.56 , 3.71 , and $3.27 \mu \mathrm{g} / \mathrm{mL}$, respectively against the P388 cell line (blood cancer cell) in vitro. A chalcone and three flavones, namely 2',4'-dihydroxychalcone, 3,5,7-trihydroxy-8-methoxyflavone, 5,7-dihydroxy3,8-dimethoxyflavone and 5-hydroxy-3,7-dimethoxyflavone were determined from the active fraction of ethyl acetate extract of leaves. Two final compounds exhibited very strong cytotoxic activity against HL60 with $\mathrm{IC}_{50}$ values of $3.43 \mu \mathrm{g} / \mathrm{mL}$ and $3.34 \mu \mathrm{g} / \mathrm{mL}$, respectively (Sufian et al., 2013). The extract of Muntingia calabura stem wood contained 15 compounds including three novel compounds $(\mathrm{M}), \quad(2 S), \quad(2 " S) \quad-, \quad(\mathrm{P}), \quad(2 S), \quad(2 " S)$ 
7,8,3',4',5',7",8",3"',4 "',5"'-decamethoxy-5,5"-biflavan; 4'-hydroxy-7,8,3',5'-tetramethoxyflavone and $(R)$-2'- $\beta$-dihydroxy-3',4'-dimethoxydihydrochacone (Kuo et al., 2014). Chemical composition study of the dichloromethane extract of the fruit of Muntingia calabura afforded squalene, triglycerides, a mixture of linoleic acid, palmitic acid and $\alpha$-linolenic acid, and a mixture of $\beta$-sitosterol and stigmasterol (Consolacion et al., 2015).

In Vietnam, Muntingia calabura grows everywhere, and it is a source of easy to find and collect, but the researches on the chemical compositions and biological activities of Muntingia calabura has been rather rare until now. In 2018, three compounds were isolated from this species including kaempferol, tiliroside, kaempferol 3-O-(6"-O-galloyl)- $\beta$-D-glucopyranoside (Le Thi Thu Hong and Vo Van Leo 2018). The study on some biological activities of this species indicated that the ethanolic extract of leaves gave good antioxidant effect with $\mathrm{IC}_{50}$ of $34.26 \mu \mathrm{g} / \mathrm{mL}$ using DPPH radical scavenging assay. In addition, it also exhibited the inhibition ability to some bacterial strains such as $P$. acnes, $S$. aureus and S. epidermidis (Duong Thi Bich et al., 2019). Aiming at finding bioactive compounds from this species in Viet Nam, herein, the extraction, isolation and identification of four compounds from acetone extracts of leaf of Muntingia calabura were reported.

\section{EXPERIMENT}

\subsection{Plant material}

The leaves of Muntingia calabura L. were collected in Can Tho city in May, 2019. Voucher specimens have been identified by Dr. Dang Minh Quan, Can Tho University. After cleaning, poor quality leaves were removed. Good material was dried at $50^{\circ} \mathrm{C}$ in order to decrease the humidity of $0-2 \%$, followed by crushing into fine powder.

\subsection{General experimental procedures}

\subsubsection{Extraction and purification}

Solid-liquid extractions were used with acetone. Solvent evaporating was accomplished by using $\mathrm{Bu}$ chi R-210 rotary evaporator system.

Thin layer chromatography (TLC) was carried out on pre-coasted silica gel $60 \mathrm{~F}_{254}(0.25 \mathrm{~mm})$ aluminium sheet (Merck) and the compounds were detected under UV $(254 / 365 \mathrm{~nm})$ fluorescence or spraying $10 \% \mathrm{H}_{2} \mathrm{SO}_{4}$ solution in ethanol, followed by heating at $105^{\circ} \mathrm{C}$ for $1-2 \mathrm{~min}$ on electric stove.
For common phase column chromatography (CPCC), silica gel 60 (0.040-0.063 mm, Merck) using increasing polarity solvent systems including $n$-hexane $(\mathrm{H})$, chloroform $(\mathrm{C})$, ethyl acetate $(\mathrm{E})$ and methanol (M) were used. Compounds were purified by re-crystallization in pure solvents.

\subsubsection{Structural elucidation and identification}

Melting point (mp.) was recorded on a melting point meter (Electrothermal 9100, UK), using capillary; UV spectra were scanned on Jenway 6315 UV-Vis photometer (UK); IR spectra were recorded on Nicolet 6700 FT-IR spectrometer (Thermo, USA) at Can Tho University. ${ }^{1} \mathrm{H}-\mathrm{NMR},{ }^{13} \mathrm{C}$-NMR, DEPT, HSQC, HMBC spectra were recorded on a Bruker AM500 FT-NMR spectrometer; Mass spectrum (MS) was recorded on mass spectrometer (HP 1100 series, LC/MSD Trap, Agilent) at Vietnam Academy of Science and Technology.

\subsection{Extraction and isolation}

The dried leaves powder $(5.0 \mathrm{~kg})$ was exhaustedly extracted with acetone $99.9 \%$ to gain acetone extract $(0.42 \mathrm{~kg})$.

The acetone extract (LA, $400 \mathrm{~g}$ ) was subjected to CP-CC with $n$-hexane and ethyl acetate (H:E) solvent systems (gradient, 0 to $100 \% \mathrm{E}$ ) as eluent to give 9 fractions (LA1-LA9).

The fraction LA2 (H:E 10:0; $8.0 \mathrm{~g}$ ) was taken CP$\mathrm{CC}$ with $n$-hexane (100\%) as eluent to obtain 6 fractions (LA21-LA26). The fraction LA25 (0.022 g) was re-crystallized in $n$-hexane to obtain compound $1(9.2 \mathrm{mg})$.

The fraction LA3 (H:E 10:0; $15.0 \mathrm{~g}$ ) was continued to CP-CC ( $n$-hexane, $100 \%)$ to afford 7 fractions (LA31-LA37). The fraction LA32 $(0.502 \mathrm{~g})$ was continued to CP-CC (n-hexane, 100\%) to give 3 fractions (LA321-LA323). The fraction LA322 $(0.347 \mathrm{~g})$ was re-crystallized in $n$-hexane to produce compound $\mathbf{3}(10.1 \mathrm{mg})$.

The fraction LA4 (H:E 9:1, $10.0 \mathrm{~g}$ ) was continued to $\mathrm{CP}-\mathrm{CC}$ with $n$-hexane and chloroform (H:C) solvent systems (9:1) to afford 8 fractions (LA41LA48). The fraction LA43 (0.804 g) was continued to $\mathrm{CP}-\mathrm{CC}$ (H:C 9:1) to give 5 fractions (LA431LA435). The fraction LA434 (0.207 g) was re-crystallized in chloroform to yield compound $2(7.4 \mathrm{mg})$.

The fraction LA5 (H:E 9:1, 7.3 g) was continued to CP-CC (H:C 9:1) to afford 3 fractions (LA51LA53). The fraction LA52 $(0.205 \mathrm{~g})$ was re-crystallized in chloroform to gain compound 4 (12.4 mg). 


\subsection{Physical characteristic and spectral data}

5-Hydroxy-7-methoxyflavone (1): Yellow amorphous powder, mp. $164-165^{\circ} \mathrm{C}$. ESI-HRMS $\mathrm{m} / z$ 2 269.0776 [M+H] $]^{+}$, UV (MeOH, $\left.\lambda_{\max }\right): 247,268$, $309 \mathrm{~nm}$; IR (KBr, v): 3072, 2843, 2360, 1605, 1155, $803,766 \mathrm{~cm}^{-1} .{ }^{1} \mathrm{H}-\mathrm{NMR}\left(\mathrm{CDCl}_{3}, 500 \mathrm{MHz}, \delta_{H} \mathrm{ppm}\right.$, $J \mathrm{~Hz})$ and ${ }^{13} \mathrm{C}-\mathrm{NMR}\left(\mathrm{CDCl}_{3}, 125 \mathrm{MHz}, \delta_{C} \mathrm{ppm}\right)$ : see Table 1.

5-Hydroxy-6,7-dimethoxyflavone (2): Yellow amorphous powder, mp. $158-159^{\circ} \mathrm{C}$. ESI-HRMS $\mathrm{m} / z$ 299.0899 $[\mathrm{M}+\mathrm{H}]^{+}$; UV (MeOH, $\left.\lambda_{\max }\right): 249,272$, $315 \mathrm{~nm}$; IR (KBr, v): 2942, 1659, 1585, 1448, 1353, $1121,760 \mathrm{~cm}^{-1}$. ${ }^{1} \mathrm{H}-\mathrm{NMR}\left(\mathrm{CDCl}_{3}, 500 \mathrm{MHz}, \delta_{H}\right.$ ppm, $J \mathrm{~Hz})$ and ${ }^{13} \mathrm{C}-\mathrm{NMR}\left(\mathrm{CDCl}_{3}, 125 \mathrm{MHz}, \delta_{C}\right.$ ppm): see Table 1 .

5-Hydroxy-3,7-dimethoxyflavone (3): Pale yellow amorphous powder, mp. $160-162^{\circ} \mathrm{C}$. ESI-HRMS<smiles>COc1cc(O)c2c(=O)cc(-c3ccccc3)oc2c1</smiles><smiles>COc1cc(O)c2c(=O)c(OC)c(-c3ccccc3)oc2c1</smiles>

5-Hydroxy-3,7-dimethoxyflavone (3) $m / z, 299.0899[\mathrm{M}+\mathrm{H}]^{+} .{ }^{1} \mathrm{H}-\mathrm{NMR}\left(\mathrm{CDCl}_{3}, 500 \mathrm{MHz}\right.$, $\left.\delta_{H} \mathrm{ppm}, J \mathrm{~Hz}\right)$ and ${ }^{13} \mathrm{C}-\mathrm{NMR}\left(\mathrm{CDCl}_{3}, 125 \mathrm{MHz}, \delta_{C}\right.$ ppm): see Table 1 .

5-Hydroxy-3,7,8-trimethoxyflavone (4): Yellow amorphous powder, mp. $175-176^{\circ} \mathrm{C}$. ESI-HRMS $\mathrm{m} / \mathrm{z} 329.1021[\mathrm{M}+\mathrm{H}]^{+}$; $\mathrm{UV}\left(\mathrm{MeOH}, \lambda_{\max }\right): 272,358$ $\mathrm{nm}$; IR (KBr, v): 2926, 2850, 1656, 1599, 1477, $1207,682 \mathrm{~cm}^{-1} .{ }^{1} \mathrm{H}-\mathrm{NMR}\left(\mathrm{CDCl}_{3}, 500 \mathrm{MHz}, \delta_{H}\right.$ ppm, $J \mathrm{~Hz})$ and ${ }^{13} \mathrm{C}-\mathrm{NMR}\left(\mathrm{CDCl}_{3}, 125 \mathrm{MHz}, \delta_{C}\right.$ ppm): see Table 1 .

\section{RESULTS AND DISCUSSIONS}

All isolated compounds had some similar characteristics as being yellow solid, absorbing UV light, producing a positive reaction to $\mathrm{FeCl}_{3}$ reagent. Typical signals of protons and carbons in 1D-NMR showed that they had the same pattern of a flavone backbone.<smiles>COc1cc2oc(-c3ccccc3)cc(=O)c2c(O)c1O</smiles>

5-Hydroxy-6,7-dimethoxyflavone (2)<smiles>COc1cc(O)c2c(=O)c(OC)c(-c3ccccc3)oc2c1OC</smiles>

5-Hydroxy-3,7,8-trimethoxyflavone (4)

Fig. 1: Chemical structures of isolated compounds

\subsection{Compound 1}

Compound 1 was obtained as a yellow amorphous powder, mp. $164-165^{\circ} \mathrm{C}$.

The molecular formula of compound 1 was speculated to be $\mathrm{C}_{16} \mathrm{H}_{12} \mathrm{O}_{4}$ (calc. for 268.0736 , eleven degrees of unsaturation) on the basis of the ESI-HRMS $\left(\mathrm{m} / \mathrm{z} 269.0776[\mathrm{M}+\mathrm{H}]^{+}\right)$.

The ${ }^{1} \mathrm{H}$-NMR spectrum of compound $\mathbf{1}$ showed eight aromatic protons, in which two protons were meta-coupled doublet signals at $\delta_{H} 6.36$ and 6.48 ppm (each, $J=2.0 \mathrm{~Hz}$ ); two multiplet signals of five protons of a single-substituted symmetric aromatic ring at $\delta_{H} 7.49-7.56(3 \mathrm{H}, m)$ and 7.86-7.88 $(2 \mathrm{H}, m)$ ppm; one singlet signal of other ring double-bonded methine group at $\delta_{H} 6.64 \mathrm{ppm}$; one methoxy group at $\delta_{H} 3.87 \mathrm{ppm}$.

The ${ }^{13} \mathrm{C}-\mathrm{NMR}$ and DEPT spectra of compound $\mathbf{1}$ appeared signals of total 16 carbons, in which there were fifteen carbons of a flavone backbone and one substituted methoxyl groups at $\delta_{C} 55.8 \mathrm{ppm}$ (further confirmed by its HMBC spectrum).

The fifteen carbons of a flavone backbone consisted of eight aromatic methine carbons at $\delta_{C} 92.7,98.2$, $105.9,126.3$ (2C), 129.1 (2C) and $131.8 \mathrm{ppm}$; two non-hydrogenated aromatic carbons at $\delta_{C} 105.7$ and $131.3 \mathrm{ppm}$; four oxygenated aromatic carbons at $\delta_{C}$ $157.8,162.2,164.0$ and $165.6 \mathrm{ppm}$ and one carbonyl group at $\delta_{C} 182.5 \mathrm{ppm}$. 
From above mentioned 1D-NMR data, compound 1 gave the characteristic spectra pattern of a flavone derivative with two substituted groups (hydroxyl and methoxyl).

Based on the spectral data analysis and comparison with those given in the literature (Rosandy et al., 2013), the structure of compound 1 was suggested as 5-hydroxy-7-methoxyflavone or techtochrysin (Figure 1).

\subsection{Compound 2}

Compound 2 was isolated as a yellow amorphous powder, mp. $158-159^{\circ} \mathrm{C}$.

The molecular formula of compound 2 was established as $\mathrm{C}_{17} \mathrm{H}_{14} \mathrm{O}_{5}$ (calc. for 298.0841) by ESIHRMS $\left(m / z 299.0899[\mathrm{M}+\mathrm{H}]^{+}\right)$.

${ }^{1} \mathrm{H}-\mathrm{NMR}$ spectrum of compound $\mathbf{2}$ appeared similar proton signals to compound $\mathbf{1}$, but it showed one less aromatic proton and one more methoxyl group than compound 1 (Table 1).

${ }^{13} \mathrm{C}$-NMR and DEPT spectra exhibited signals of total 17 carbons, which was more one methoxyl carbon than compound $\mathbf{1}$. Its carbon signals are similar to those of a flavone, but compound $\mathbf{2}$ contained less one methine carbon and more one oxygenated aromatic carbon. This indicated that compound $\mathbf{2}$ had two substituted methoxyl groups and one substituted hydroxyl group (Table 1).
Moreover, the 1D-NMR spectral data of compound 2 were similar to those of 5-hydroxy-6,7-dimethoxyflavone (Figure 1) given in the literature (Rosandy et al., 2013). All correlation signals between protons and carbons in HSQC and HMBC spectral data of compound 2 conformed with the chemical structure of 5-hydroxy-6,7-dimethoxyflavone. From these evidences, compound $\mathbf{2}$ was determined as 5-hydroxy6,7-dimethoxyflavone.

\subsection{Compound 3}

Compound 3 was received as pale-yellow amorphous powder, mp. $160-162^{\circ} \mathrm{C}$.

Most of 1D-NMR spectral signals were very similar to those of compound $\mathbf{2}$ (Table 1). However, there was a changing position of one methoxyl group from C-6 to C-3 of the flavone backbone which was confirmed by HMBC spectrum. The molecular formula of compound $\mathbf{3}$ was also speculated to be $\mathrm{C}_{17} \mathrm{H}_{14} \mathrm{O}_{5}$ (calc. for 298.0841) on the basic of the ESI-HRMS $\left(\mathrm{m} / z 299.0899[\mathrm{M}+\mathrm{H}]^{+}\right)$. Spectral data of compound $\mathbf{3}$ were compared with those given in the literature (Sae-wong, 2011). As a result, compound 3 was identified as 5-hydroxy-3,7-dimethoxyflavone (Figure 1).

\subsection{Compound 4}

Compound 4 was crystallized in chloroform as a yellow amorphous powder, mp. $175-176^{\circ} \mathrm{C}$.

Table 1: ${ }^{1} \mathrm{H}-\mathrm{NMR}$ and ${ }^{13} \mathrm{C}$-NMR data of isolated compounds

\begin{tabular}{|c|c|c|c|c|c|c|c|c|}
\hline \multirow{2}{*}{ C-position } & \multicolumn{2}{|c|}{ Compound 1} & \multicolumn{2}{|c|}{ Compound 2} & \multicolumn{2}{|c|}{ Compound 3} & \multicolumn{2}{|c|}{ Compound 4} \\
\hline & ${ }^{1} \mathrm{H}$ & ${ }^{13} \mathrm{C}$ & ${ }^{1} \mathrm{H}$ & ${ }^{13} \mathrm{C}$ & ${ }^{1} \mathrm{H}$ & ${ }^{13} \mathrm{C}$ & ${ }^{1} \mathrm{H}$ & ${ }^{13} \mathrm{C}$ \\
\hline 2 & & 164.0 & & 163.5 & & 155.9 & & 155.9 \\
\hline 3 & $6.64(s)$ & 105.9 & $7.04(s)$ & 104.9 & & 139.7 & & 139.5 \\
\hline 4 & & 182.5 & & 182.4 & & 179.0 & & 179.3 \\
\hline 5 & & 162.2 & & 152.0 & & 162.1 & & 157.5 \\
\hline 6 & $6.36(d, 2.0)$ & 98.2 & & 132.0 & $6.35(d, 2.0)$ & 98.0 & $6.43(s)$ & 95.6 \\
\hline 7 & & 165.6 & & 158.9 & & 165.6 & & 158.6 \\
\hline 8 & $6.48(d, 2.0)$ & 92.7 & $6.99(s)$ & 91.7 & $6.45(d, 2.0)$ & 92.2 & & 129.0 \\
\hline 9 & & 157.8 & & 152.8 & & 156.9 & & 148.7 \\
\hline 10 & & 105.7 & & 105.3 & & 106.2 & & 105.5 \\
\hline $1^{\prime}$ & & 131.3 & & 130.6 & & 130.5 & & 130.7 \\
\hline $2^{\prime}$ & 7.86-7.88 (m) & 126.3 & $8.10-8.12(\mathrm{~m})$ & 126.4 & $8.05-8.07(\mathrm{~m})$ & 128.4 & $8.14-8.16(\mathrm{~m})$ & 128.5 \\
\hline $3^{\prime}$ & 7.49-7.56(m) & 129.1 & $7.57-7.63(\mathrm{~m})$ & 129.1 & $7.50-7.52(\mathrm{~m})$ & 128.6 & $7.52-7.54(\mathrm{~m})$ & 128.7 \\
\hline $4^{\prime}$ & 7.49-7.56 (m) & 131.8 & $7.57-7.63(\mathrm{~m})$ & 132.1 & $7.50-7.52(\mathrm{~m})$ & 130.9 & $7.52-7.54(\mathrm{~m})$ & 131.0 \\
\hline $5^{\prime}$ & $7.49-7.56(\mathrm{~m})$ & 129.1 & $7.57-7.63(\mathrm{~m})$ & 129.1 & $7.50-7.52(\mathrm{~m})$ & 128.6 & $7.52-7.54(\mathrm{~m})$ & 128.7 \\
\hline $6^{\prime}$ & 7.86-7.88 (m) & 126.3 & $8.10-8.12(\mathrm{~m})$ & 126.4 & $8.05-8.07(\mathrm{~m})$ & 128.4 & $8.14-8.16(\mathrm{~m})$ & 128.5 \\
\hline $3-\mathrm{OCH}_{3}$ & & & & & $3.87(s)$ & 60.4 & $3.88(s)$ & 60.4 \\
\hline $6-\mathrm{OCH}_{3}$ & & & $3.94(s)$ & 60.0 & & & & \\
\hline 7- $\mathrm{OCH}_{3}$ & $3.87(s)$ & 55.8 & $3.75(s)$ & 56.5 & $3.87(s)$ & 55.8 & $3.95(s)$ & 56.4 \\
\hline $8-\mathrm{OCH}_{3}$ & & & & & & & $3.91(s)$ & 61.7 \\
\hline
\end{tabular}

Note: All spectra were recorded in $\mathrm{CDCl}_{3}, 500 / 125 \mathrm{MHz}$. 
The molecular formula of compound 4 was established as $\mathrm{C}_{18} \mathrm{H}_{16} \mathrm{O}_{6}$ (calc. for 328.0947) by ESIHRMS $\left(m / z, 329.1021[\mathrm{M}+\mathrm{H}]^{+}\right)$.

${ }^{1} \mathrm{H}-\mathrm{NMR}$ spectrum of compound $\mathbf{4}$ appeared similar proton signals to compound $\mathbf{3}$, but it showed less one aromatic proton and more one methoxyl group (Table 1).

${ }^{13} \mathrm{C}$-NMR and DEPT spectra revealed total 18 signals of carbon. This compound had more one methoxyl carbon than compound $\mathbf{3}$. In the similar carbon signals of a flavone, compound $\mathbf{4}$ contained less one methine carbon and more one oxygenated aromatic carbon than compound 3 . It indicated that compound $\mathbf{4}$ had three substituted methoxyl groups and one substituted hydroxyl group (Table 1).

Furthermore, the 1D-NMR spectral data of compound 4 were similar to those of 5-hydroxy-3,7,8trimethoxyflavone (Figure 1) given in the literature (Yusof et al., 2013). Assignments of all protons and carbons in compound $\mathbf{4}$ were also made by HSQC and HMBC spectral correlations in compound $\mathbf{4}$ for all proton and carbon signals were compatible with the chemical structure of 5-hydroxy-3,7,8-trimethoxyflavone. From the spectral data analysis, compound 4 was identified as 5-hydroxy-3,7,8-trimethoxyflavone.

\section{CONCLUSIONS}

From acetone extracts of the leaves of Muntingia calabura $L$. collected in Can Tho city, four known flavonoid compounds were isolated and identified as 5-hydroxy-7-methoxyflavone (1), 5-hydroxy6,7-dimethoxyflavone (2), 5-hydroxy-3,7-dimethoxyflavone (3) and 5-hydroxy-3,7,8-trimethoxyflavone (4). Further studies are proposed to confirm their bioactivities as well to isolate other bioactive components from this species.

\section{ACKNOWLEDGMENT}

This study is funded in part by the Can Tho University Improvement Project VN14-P6, supported by Japanese ODA loan.

The authors also thank Dr. Dang Minh Quan for plant identification.

\section{REFERENCES}

Chen, J. J., Lin, R. W., Duh, C. Y., Huang, H. Y. and Chen, I. S., 2004. Flavones and cytotoxic constituents from the stem bark of Muntingia calabura. Journal of Chinese Chemical Society. 51(3): 665-70.
Consolacion, Y. R., Maria, C. S. T, Irving, D. C., and Chien, C. S., 2015. Chemical constituents of Muntingia calabura L. Der Pharma Chemica. 7(5): 136-141.

Duong Thi Bich, Huynh Ngoc Trung Dung, Tri Kim Ngoc, Le Phuong Hiep and Nguyen Van Ba, 2019. Examing antioxidant activity and aganist acnecaused bacteria of Muntingia calabura L. leaves. Can Tho University Journal of Science. 55 (special 1): 91-97 (in Vietnamese).

Kuo, W. L., Liao, H. R. and Chen, J. J., 2014. Biflavans, Flavonoids, and a Dihydrochalcone from the Stem Wood of Muntingia calabura and Their Inhibitory Activities on Neutrophil Pro-Inflammatory Responses. Molecules. 19(12): 20521-20535.

Le Thi Thu Hong and Vo Van Leo, 2018. Extraction, isolation of flavonoid compounds from leaves of Muntingia calabura L. (Muntingiaceae). Vietnam Journal of Pharmacy. 58 (in Vietnamese).

Mahmood, N. D., Nasir, N. L. M., Rofiee, M. S., et al., 2014. Muntingia calabura: A review of its traditional uses, chemical properties, and pharmacological observations. Pharmaceutical Biology. 52(12): 1598-1623.

Pereira, G. A., Arruda, H. S., Morais, D. R., Eberlin, M. N. and Pastore, G. M., 2018. Carbohydrates, volatile and phenolic compounds composition, and antioxidant activity of calabura (Muntingia calabura L.) fruit. Food Research International.108:264-273.

Rosandy, A. R., Din, L. B., Yaacob, W.A., et al., 2013. Isolation and characterization of compounds from the stem bark of Uvaria rufa (Annonaceae). The Malaysian Journal of Analytical Sciences. 17(1): 50-58.

Sae-wong, C., 2011. Anti-inflammatory activity of Kaempferia parviflora Rhizomes. $\mathrm{PhD}$ thesis (in pharmaceutical sciences). Prince of Songkla University. 126 pages.

Sufian, A. S., Ramasamya, K., Ahmat, N. and Zakaria, Z., 2013. Isolation and identification of antibacterial and cytotoxic compounds from the leaves of Muntingia calabura L.. Journal of Ethnopharmacology. 146(1): 198-204.

Yusof, M. I. M., Salleh, M. Z., Kek, T. L., Ahmat, N., Azmin, N. F. N. and Zakaria, Z. A., 2013. Activityguided isolation of bioactive constituents with antinociceptive activity from Muntingia calabura L. leaves using the formalin test. Evidence-based complementary and alternative medicine. ID715074: 1-9. 